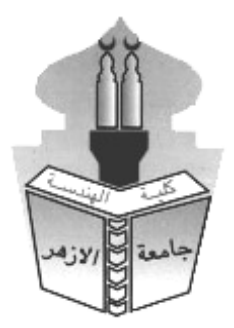

\title{
SMART MATERIALS AND IOT ADAPTABILITY IN ARCHITECTURE AS TRANSFORMATIVE ELEMENTS IN THE CONCEPT OF CREATIVE CHILDREN SPACES
}

\author{
Vitta Abdel Rehim Ibrahim \\ Architecture Department, Pyramids Higher Institute for Engineering and Technology \\ ( P.H.I.), $6^{\text {th }}$ of October, Cairo, Egypt \\ E-mail: Vitta174@hotmail.com
}

\begin{abstract}
As a result of the development of materials, can be employed in the creation of spaces and forms within the buildings more interesting and remarkable, converting materials that meet environmental and structural function to more benefit from the distinctive materials in buildings used for children, especially those buildings that contribute to the output of positive energy in the form of indirect education - where Modern educational approaches are aimed at creating a creative and innovative generation. The creative environment for children is the environment that contributes to raising the child's imagination and expectations according to elements that help in using them in an unusual way.Here, the creative child possesses unlimited imagination and architecture must respond to those needs for stimulating imagination with what smart materials can offer. Smart materials are more multifunctional "changeability and responsiveness according to needs". Being flexible and adaptable to the environment by improving building's impact to provide healthier and more efficient environment.The research aims to utilize concepts of smart materials and intelligence techniques that act more dynamically. IoT Internet of things emerged the architecture spaces giving more smart potentials.

The application of "InternetofThings" in the architectural spaces affects the built environment. The research question is whether the use of smart materials and IoT technology in children's spaces provides a creative an innovative environment?

The dramatic increase in technology with new systems has encouraged the study of the different characteristics of building materials. Through the analysis of some case studies that deal with children's spaces, there is a presence of the characteristics and practices of intelligence in architecture. The findings confirm that the use of smart materials and new technological techniques in children's spaces is the source of the positive benefits that create a cognitive relationship between the child and his environment.Through the lessons learned from the analytical study, some ideas were proposed to enhance the concept of creativity in architecture while giving a new dimension to the space and time.
\end{abstract}

KEYWORDS: Smart materials, IoT, Creativity, Children Spaces ,Built Environment

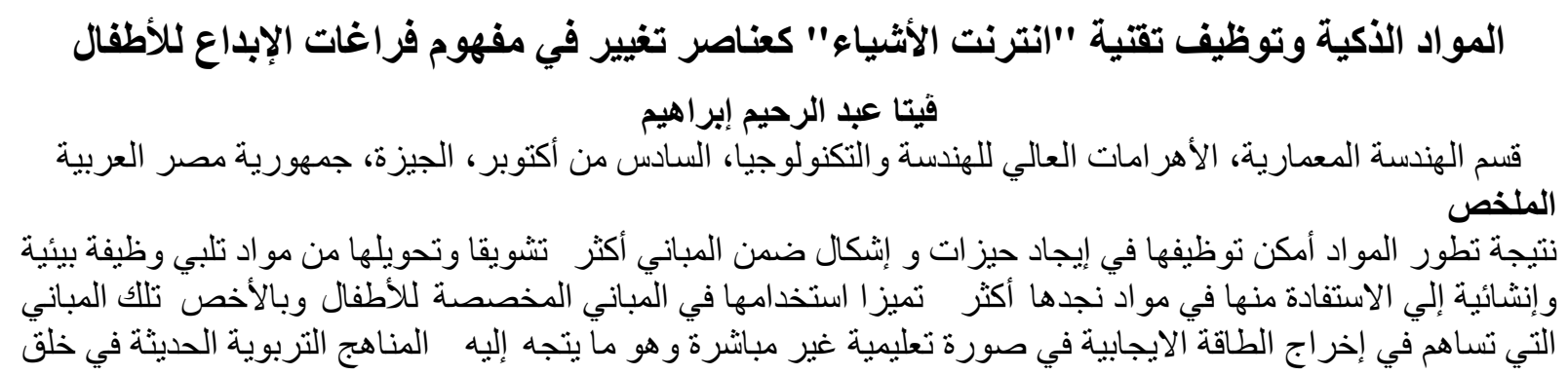




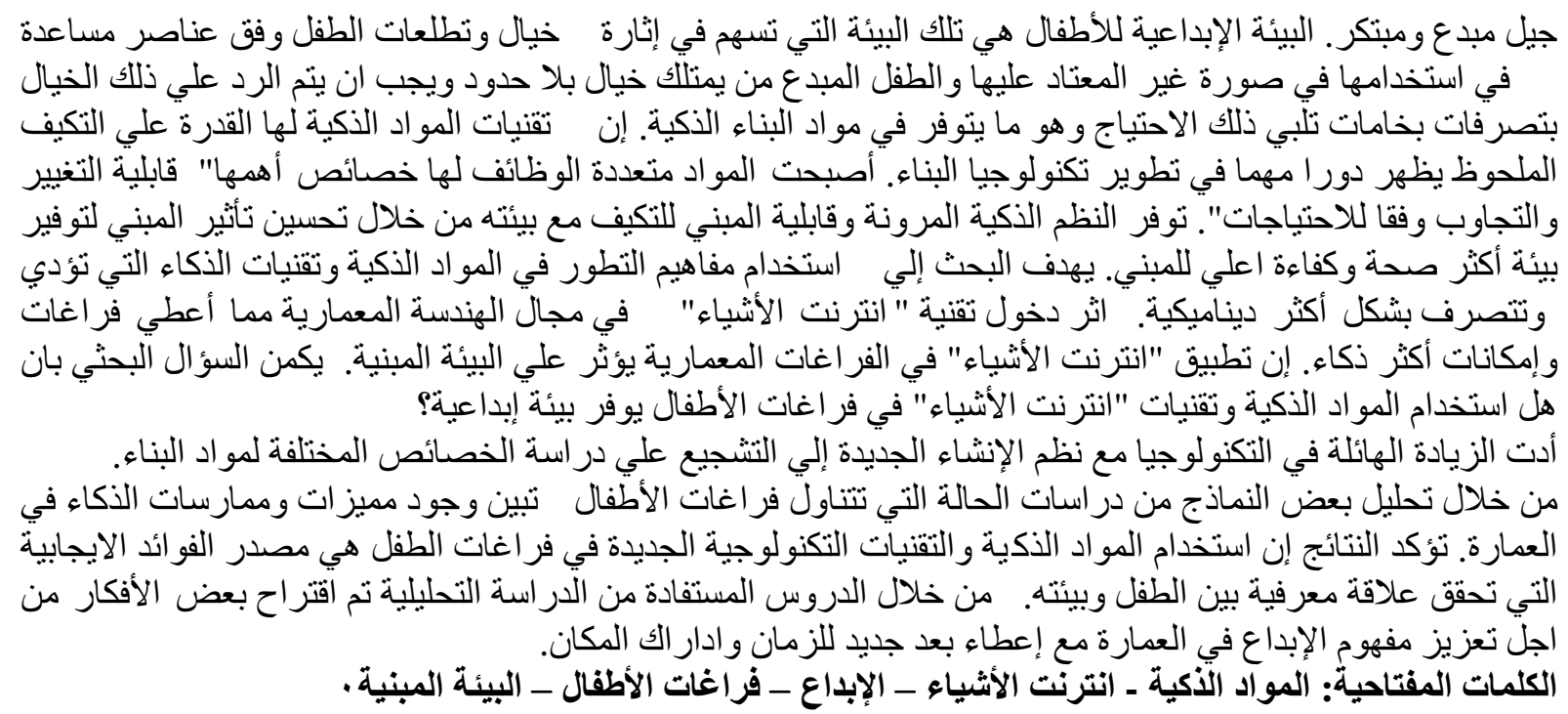

\section{1- INTRODUCTION}

Smart materials appearance in architecture is of great significance to meet needs and requirements of the $21^{\text {st }}$ century. It inspires architects to provide better conditions for occupants. (Nasr, 2017)

New materials are being developed for advanced solutions to long-term problems. Exploring these technologies leads to discovering new materials considered as a multipurpose material; for creative architecture solutions. (Mohamed, 2017)

This research focuses on the incorporation of smart materials technologies in architecture engineering expound its prospective to create a vast influence on architectural creating new dimensions to form and space in children's buildings fostering creativity and imagination.

\section{1-1 Research Objectives}

Study the influence of Smart materials and potentials of nanotechnology on architecture to investigate its role and function as a flexible approach in architecture application. Introduce the emergence of the Internet of Things (IoT) concept in Architecture. Show and propose how smart materials and its Innovative technologies application can be applied in children spaces as an approach for a creative environment.

\section{1-2 Research methodology}

The research follows theoretical descriptive, analytical method. The Theoretical Descriptive part is to: investigate design considerations for children for creative environments, discover various aspects of technologies include smart materials classification and fundamentals and advantages, study emergence of Internet of Things (IoT), explore their effect on Architectural form elements, function and spaces of children.

The analytical study is to: analyze two case studies, summarizing results of comparison, followed by proposed ideas to consider implementation of technology in children Architectural spaces.

\section{2-Shaping the future: Designing for children}

Space and the child relationship is of great importance, that support the child to grasp the utmost compatibility of necessities of the activity practiced within these spaces.

Technology has influenced the child's human needs and design his architectural space.

Smart Architecture techniques in designing internal spaces to provide and respond to children needs applying concepts of interaction and integration in spaces to stimulate creativity. (Dobbins, 2018) 
Advances of the architectural spaces and the emergence of information technology, reflected on changing child space and the indications of his growth. Technological considerations have an huge impact on the child's developmental features and human needs. Information technology is one of the hierarchical levels of the child's human needs. Fig. ( 1 )

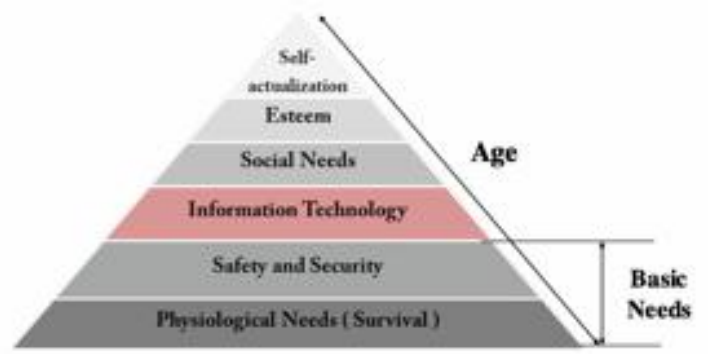

Fig (1) Information technology is one of the hierarchical levels of the child's needs. ((Desouky et Al., 2016)

Where the information technology aid in the improvement of design solutions to spaces creating more flexible, adaptable and ease the movement of the child within.

\section{2-1-Design consideration for Children:}

Some Architectural major bodies push for localized standards, those targeting to encourage a safe and healthy learning circumstances, architects should think of spaces to support selflearning, promote play, creating the right level of social interaction between ages.

\section{2-2 Creative environment for children:}

It is the environment in the child grows and develops. The environment either stimulates creativity, supports it, or undermines and impedes.

With the speed of progress in this era and the involvedness of the technology fields in the information age the need to address creativity is increasing. To develop the creative abilities of the child, he should be exposed to many of the real experiences that contribute to the expansion of innovations, and encourage the continuation, and the positive outlook.

The built environment has a great influence on the creative process, which provides an atmosphere and conditions appropriate to support the creative energies and promote a culture of creativity and innovation. Creativity does not happen randomly but is enhanced by environmental factors.

2-3 Child centric design: (Dobbins, 2018)

\begin{tabular}{|l|l|}
\hline safety & safety is crucial for children, referring to soft edges/ soft materials in soft designs. \\
\hline play & $\begin{array}{l}\text { spaces that permit the needed natural creativity and independence of play, and } \\
\text { cherish it, by creating an adaptable, a multi-use space. }\end{array}$ \\
\hline Liberation & $\begin{array}{l}\text { Facilitating children to intermingle or navigate within the spaces, letting the } \\
\text { children be free and self assisted within the design, children can interact with the } \\
\text { space. }\end{array}$ \\
\hline $\begin{array}{l}\text { Adaptability/ } \\
\text { Openness }\end{array}$ & flexible adapted spaces to any situation, open, and accessed to nature. \\
\hline Understanding & create specialized spaces for children that foster their freedom and creativity \\
\hline
\end{tabular}

\section{3- SMART MATERIALS}

The role of materials has transformed from their pre-modern role of being secondary to architectural needs where new formal responses and functional implementation increased. Materials of Façade disconnected from the building's structure and infrastructure, led to freeing the material choice. The interior and exterior Buildings' materials developed to be part of a design. Smart materials will reshape building surfaces, walls and facades, enhancing their design from a static to an interactive. (Addington et Al., 2005)

Smart materials defined as "highly engineered materials that respond intelligently to their environment" (Addington et Al., 2005) They can achieve sensing and actuating functions, upon the applying of an external stimulus (form of light, sound, temperature, electric field, 
magnetic field and stress). Their properties are changeable and therefore response to transient needs. Smart materials can be classified into two types. (Makakli, 2017) (Table (1 ) illustrated the two types of smart materials classification):

Table (1 ) describes classification of smart materials(Author adapted from: (Addington et al., 2005)

\begin{tabular}{|c|c|c|}
\hline \multicolumn{3}{|c|}{ Type 1 smart materials property changing - Chromic or color changing smart materials } \\
\hline characteristics & Photochromics & -Materials that can change color upon exposed to light \\
\hline \multirow{10}{*}{$\begin{array}{l}\text { change their } \\
\text { optical } \\
\text { properties } \\
\text { under different } \\
\text { external stimuli } \\
\text { (e.g. heat, light } \\
\text { or a chemical } \\
\text { environment) } \\
\text { which often } \\
\text { perceived as a } \\
\text { color change. }\end{array}$} & Thermochromics & $\begin{array}{l}\text { - Materials can change color due to changes in temperature } \\
\text { - Have reversible changes }\end{array}$ \\
\hline & Mechanochromics & $\begin{array}{l}\text { Materials can change color due to imposed stresses and / or } \\
\text { deformations }\end{array}$ \\
\hline & Chemochromics & $\begin{array}{l}\text { - Materials can change color when exposed to chemical } \\
\text { environments }\end{array}$ \\
\hline & Elctrochromics & $\begin{array}{l}\text { - A reversible color change of a material caused by application of an } \\
\text { electric current. }\end{array}$ \\
\hline & $\begin{array}{l}\text { Phase - changing } \\
\text { materials }\end{array}$ & $\begin{array}{l}\text { - Many materials can exist in several different physical states- gas, } \\
\text { liquid or solid. Known as phases. }\end{array}$ \\
\hline & Conducting polymers & $\begin{array}{l}\text {-Change their electrical conductivity in response to a change in the } \\
\text { strength of an electric field applied to the material. }\end{array}$ \\
\hline & $\begin{array}{l}\text { Rheological property- } \\
\text { changing materials }\end{array}$ & $\begin{array}{l}\text { Properties of flowing matter: fluids and viscous materials } \\
\text { - change their properties in response to electric or magnetic field }\end{array}$ \\
\hline & $\begin{array}{l}\text { Liquid crystal } \\
\text { technologies }\end{array}$ & $\begin{array}{l}\text { An intermediate phase between crystalline solids and isotropic } \\
\text { liquids, Sensitive to electrical fields, applicable for optical displays }\end{array}$ \\
\hline & $\begin{array}{l}\text { Suspended particle } \\
\text { displays }\end{array}$ & $\begin{array}{l}\text { Activated electrically, able to change from an opaque to a clear } \\
\text { color instantly and vice-versa. }\end{array}$ \\
\hline & Other type 1 materials & $\begin{array}{l}\text { Shape- changing gels or crystals, can absorb huge amounts of wa } \\
\text { and when drying out, can revert to their original sizes }\end{array}$ \\
\hline
\end{tabular}

Type 2 Smart materials - energy-exchanging: Energy fields- environments - surround all materials \begin{tabular}{l|l}
\hline characteristics & Light - emitting materials \\
\hline
\end{tabular}

\begin{tabular}{|c|c|c|c|}
\hline \multirow{8}{*}{$\begin{array}{l}\text { When the } \\
\text { energy state of } \\
\text { a given } \\
\text { material is } \\
\text { equivalent to } \\
\text { the energy state } \\
\text { of its } \\
\text { surrounding } \\
\text { environment, } \\
\text { then the } \\
\text { material is in } \\
\text { equilibrium. }\end{array}$} & & \multicolumn{2}{|c|}{$\begin{array}{l}\text { The emission of light due to incident energy, Light caused by the } \\
\text { re-emission of energy in wavelengths in the visible spectrum }\end{array}$} \\
\hline & & \multicolumn{2}{|c|}{ Produces light without a corresponding heat output. } \\
\hline & \multirow{6}{*}{$\begin{array}{l}\text { Luminescene } \\
\text { Chemoluminescence } \\
\text { Electroluminescence, } \\
\text { Fluorescence, } \\
\text { phosphorescence } \\
\text { Basic semiconductor } \\
\text { phenomena } \\
\text { Photovoltaics, leds, } \\
\text { transistors, } \\
\text { thermoelectrics }\end{array}$} & \multicolumn{2}{|c|}{$\begin{array}{l}\text { The voltage provides the energy required, Widely used for light } \\
\text { strips }\end{array}$} \\
\hline & & \multicolumn{2}{|r|}{$\begin{array}{l}\text { onductor nor good insulators } \\
\text { surrounding temperatures are varied }\end{array}$} \\
\hline & & $\begin{array}{l}\text { phototransistors convert } \\
\text { radiant energy from light } \\
\text { into a current. } \\
\text { Common LED based on } \\
\text { the converse of } \\
\text { photovoltaic effects. }\end{array}$ & 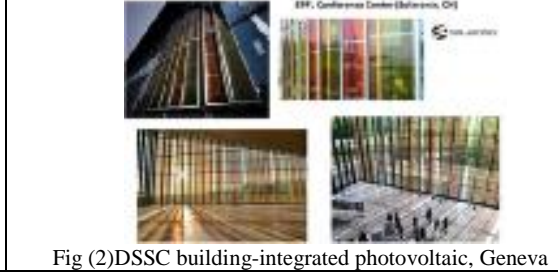 \\
\hline & & \multicolumn{2}{|c|}{$\begin{array}{l}\text { mechanical force applied can produce a deformation produces an } \\
\text { electric voltage }\end{array}$} \\
\hline & & \multicolumn{2}{|c|}{ to revert or remember or previously memorized or preset shape. } \\
\hline & & \multicolumn{2}{|c|}{ Polymers can be easily fabricated in a number of different forms. } \\
\hline
\end{tabular}

3-1 Conceptual Characteristics of smart materials and systems (Addington et Al., 2005) Immediacy: respond in real time transiency:respond to more than one environmental state self-actuation: intelligence is internal to rather than external to the material selectivity: their response is discrete and predictable

directness: the response is local to the activating event 


\section{3-2 Fundamental characteristics of Smart Materials (Addington et Al., 2005)}

\begin{tabular}{|c|c|}
\hline $\begin{array}{l}\text { property change capability: mecahnism affects the internal } \\
\text { energy of the material by altering the materials molecular } \\
\text { structure or microstrucutre : absorbs the input energy and under } \\
\text { goes a change. }\end{array}$ & $\begin{array}{l}\text { energy exchange capability:changes energy state of the material } \\
\text { composition but does not alter the material } \\
\text { (piezoelectrics, pyroelectrics, photovoltics) }\end{array}$ \\
\hline $\begin{array}{r}\text { Fundamental } \\
\text { of smart }\end{array}$ & $\begin{array}{l}\text { Characteristics } \\
\text { materials }\end{array}$ \\
\hline $\begin{array}{l}\text { discrete size/ location: less to interfere with the environment } \\
\text { that they are measuring and less to require calibration } \\
\text { adjustments }\end{array}$ & $\begin{array}{l}\text { reversibility/ directionality: reverse their input and output } \\
\text { energy forms } \\
\text { (shape memory alloys) }\end{array}$ \\
\hline
\end{tabular}

\section{3-3 Impact of Nanotechnology in developing building materials:}

Nanotechnology has the ability of generating new materials, tools, and systems by captivating the molecular levels consuming properties that arise in those levels. (Gharabaaghi et Al., 2014). It includes materials science and many other scientific areas. (Makakli, 2017) It has influenced building methods and facades design, led to the production of building materials with new functional, aesthetical and environmental properties. Table (2) effect of nanotechnology on materials.

Table ( 2 ) Applications of nanotechnology (Aysin et AL., 2014)

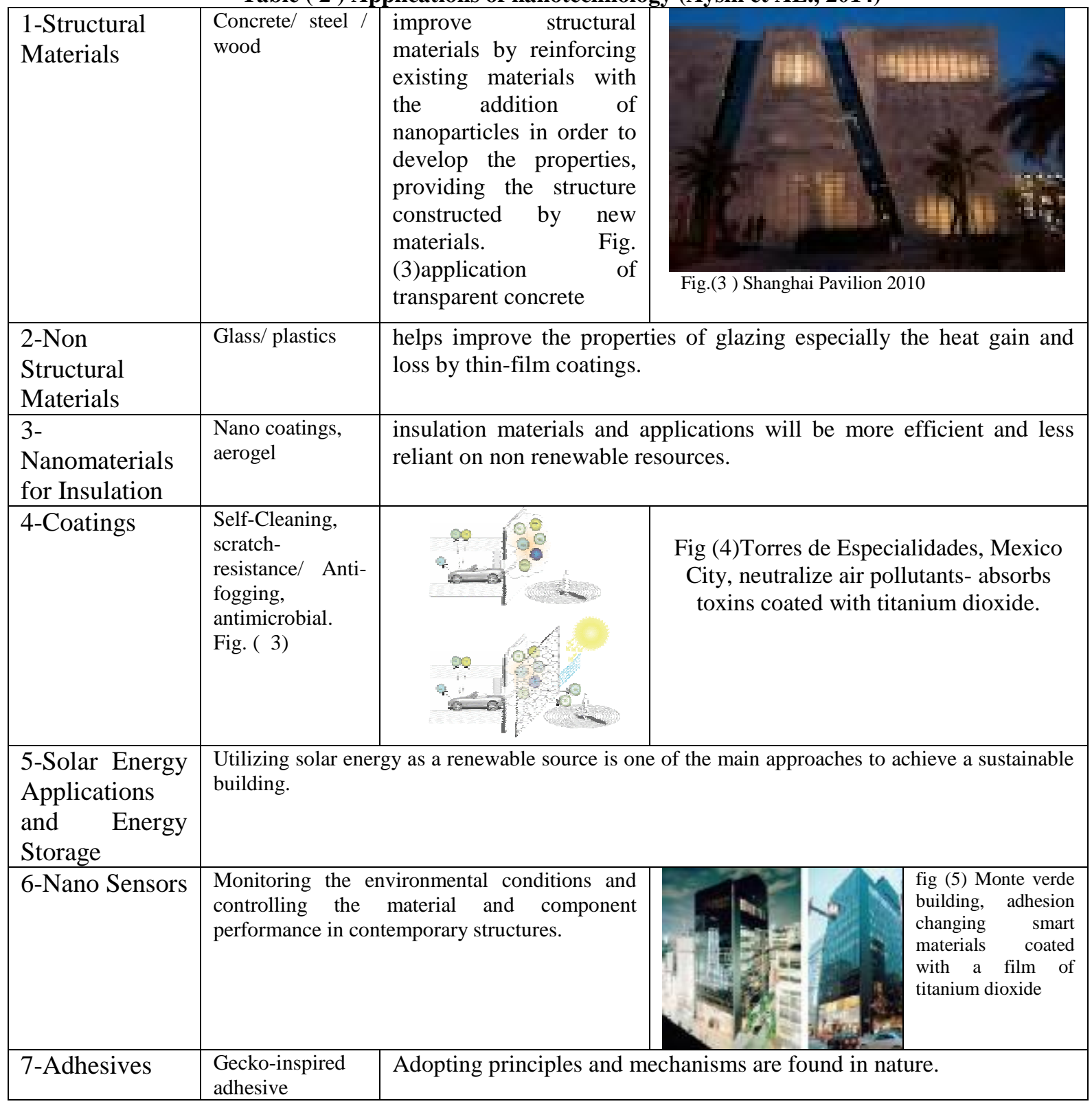


3-4 Advantages of smart materials: (Roy, 2016)

- Cost Effective $\bullet$ High strength, toughness. Increased durability. $\bullet$ High resistance to chemical corrosion, abrasion. - Easy Manufacturing and installation procedures.

Architecture is described as responsive, dynamic or interactive with emergence and wide spread of new materials, technologies and electronic computer systems.

\section{4- IoT: Revisiting the design context}

The term Internet of things (IoT) was first generated by Kevin Ashton in late 90s, approached widely in different domains by the progress of technologies of communication and mainly wireless communications. (Sun et al., 2018) Internet of things is a network, embedded with software, electronics, sensors, actuators and network connectivity, that allows connection and exchanging of data between these objects. IoT connects everything. (Yogi et Al., 2018) allowing an object to communicate, converts the devices from being smart by communication and computer embedded applications to revolutionize human experience.

IoT can be defined as "a set of technologies for retrieving the data gathered by numerous devices throughout wireless networks" (Park et Al., 2018) They are transforming ways people live. Internet can be in Everything, redefining the way people interact with each other and objects they are surrounded by. (Sun et al., 2018) Changing every feature of the building - how we inhabit, manage and build them. Fig ( 6 ) illustrates application of IoT

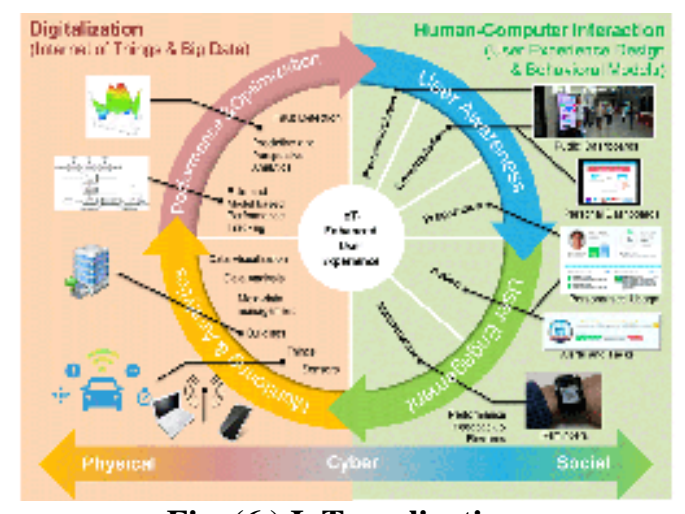

\section{5-Digital Technology gives new dimension for time and space:}

The information revolution - as digital technology- altered the objectives of thinking and creative architecture, removing the borders amongst the material and the information, the truth and imagination, organic and inorganic. (Rafaat, 2007) There is a new time and space relationship that forms the city. The spatial description is no longer static but moves towards post-imaging programs separated by data exchange.

\section{Smart materials and IoT gave new potentials in Architecture perception. \\ 5-1 Multimedia architecture:}

Media intervened in the architectural language by changing its outer face. The electronic media had a huge influence on the formation of the urban space in the aesthetic language that spread in the neon and laser advertising boards with photos and facades. The walls turn into information carriers. (Rafaat, 2007)

\begin{tabular}{|l|l|}
\hline & \\
\hline $\begin{array}{l}\text { Fig ( 7 ) Multimedia façade - Parinee Tower - Mumbai } \\
\text { - India- Arup - the building façade integrated with } \\
\text { LED screens and various lighting features for } \\
\text { multimedia displays }\end{array}$ & $\begin{array}{l}\text { Fig. ( 8) Media Architecture - Zhuhai Opera House in } \\
\text { Zhuhai, China, two shell, new urban perceptions, color } \\
\text { the city, dynamic lighting creative passage, create a } \\
\text { common platform for play. }\end{array}$ \\
\hline
\end{tabular}




\section{5-2 Interaction Design:}

Interaction is the communication between the user and the computer, whether direct or indirect. With the growth of different cultures, human behavior has been persuaded by technological progress the appearance of Internet networks, the designer supports the spirit of interaction makes designs often require contribution and interaction between individuals.

Interactive Architecture design commands the study of the users' necessities and behaviors inside the place. Interactive Interior spaces integrate the physical dimensions of the space and the electronic dimensions are integrated without canceling each other. The interaction between the dimensions of the structure of the space, which is divided into:

Multimedia Architecture is considered an attract to create a new art characterized by the interactive aspect, both physical and mental activity, the digital revolution and the emergence of the computer helped in enriching and implementing the effectiveness larger and more accessible. Many styles enhance the artistic aesthetic aspects, and can develop the cultural, behavioral and entertainment aspects.

\section{Contemporary boundary}

Boundary definition is a real or notional line specifying the boundaries of an area. Therefore, the boundary is static and can be described and its limit for marking prescribes that is tangible and can be a visual piece.

Implementing smart materials in architectural design maintains the vocabulary of the two dimensional surface. The spatial envelope behaves like a boundary. (Addington et Al., 2005)

Responsive elements are critical to explore the aesthetic expression as a technical solution and can present new architectural features in building, introducing dynamic qualities. A building can have multiple configurations, according to time of the day, the season and the use. (Ellika et Al., 2019)

\section{6- Technological development and its impact in re/designing the architectural space of} the child: (Desouky et Al., 2016 )

Components space limits and to flow and interactive dynamics and movement of the traditional structural

architectural elements

space:

Special criteria (scale and to the composition of communication units and criteria for proportions, balance, and spatial elements and flexibility of its formation. the visual the system of elements, became easy to develop to accommodate the vision of the shape and fixed $\_$various technological tools to develop the child's space: configuration)

Criteria for (color, the quality acoustics, of the space: ventilation) determinates.

became more flexible spaces, developed to provide galleries for activities to gather children to interact positively among them various technological tools to develop the child's intelligence.

lighting, has become an interaction between the space texture, and the surrounding environment the use of smart building materials, and the adoption of its characteristics on the Architectural form. spaces embedded with electronic systems and modern technological methods, and there are adaptations for ventilation and lighting to suit the child. 


\section{6-1 Design dimensions affecting the architectural spaces of children: (Desouky et Al., 2016 )}

\begin{tabular}{|c|c|c|c|}
\hline - Form: & $\begin{array}{l}\text { - The human } \\
\text { dimension: }\end{array}$ & $\begin{array}{l}\text { - Environmental } \\
\text { dimension: }\end{array}$ & $\begin{array}{l}\text { - Physical } \\
\text { dimension: }\end{array}$ \\
\hline $\begin{array}{l}\text { - Separation of free } \\
\text { and dynamic external } \\
\text { configuration of the } \\
\text { internal space, and the } \\
\text { transformation of the } \\
\text { exterior space } \\
\text { - Convert some spaces } \\
\text { into spaces with open } \\
\text { ceilings, while the } \\
\text { facades are connected } \\
\text { in one composition. } \\
\text { - Non-compliance, } \\
\text { flexibility and } \\
\text { changeability. }\end{array}$ & $\begin{array}{l}\text { - The space has } \\
\text { become a median for } \\
\text { the transfer of } \\
\text { information. } \\
\text { - Helped to save time } \\
\text { and effort } \\
\text {-Achieving } \\
\text { communication } \\
\text { between family } \\
\text { members and children } \\
\text { no matter how far } \\
\text { away } \\
\text { - Transform elements } \\
\text { built into smart } \\
\text { elements } \\
\text { - Development of the } \\
\text { sensory dimension of } \\
\text { the child and raise the } \\
\text { level of intelligence }\end{array}$ & $\begin{array}{l}\text { - Develop the design } \\
\text { process with programs } \\
\text { compatible of the } \\
\text { building with the } \\
\text { surrounding } \\
\text { environment } \\
\text { - The use of natural } \\
\text { and artificial lighting } \\
\text { analysis systems to } \\
\text { determine their impact } \\
\text { on the user and find } \\
\text { solutions } \\
\text { - Achieving thermal } \\
\text { comfort for users } \\
\text { - help building to } \\
\text { make it sustainable } \\
\text { and healthy for the } \\
\text { child }\end{array}$ & $\begin{array}{l}\text { - Develop of use of } \\
\text { smart materials } \\
\text { - The emergence of } \\
\text { smart materials } \\
\text { integrated with control } \\
\text { systems and } \\
\text { communications. } \\
\text { - The interaction of the } \\
\text { child with nature and } \\
\text { the surrounding } \\
\text { environment adapting } \\
\text { to changes, and } \\
\text { development of his } \\
\text { sensing to the } \\
\text { surrounding } \\
\text { environments. } \\
\text { - Link building with } \\
\text { smart systems, control } \\
\text { and provide safety of } \\
\text { the child. }\end{array}$ \\
\hline
\end{tabular}

\section{6-2 Smart Applications in Children spaces:}

\begin{tabular}{|l|l|l|}
\hline 1- Study spaces & $\begin{array}{l}\text { Tilt and touch table: } \\
\text { Interactive education }\end{array}$ & \\
\hline 2- Interactive play & Interactive floor: & \\
\hline 3- Museums & $\begin{array}{l}\text { Interactive spaces/ virtual } \\
\text { reality/ Internet of things }\end{array}$ & \\
\hline 4-Open spaces & Interactive/ smart spaces & \\
\hline
\end{tabular}

\section{7- APPLICATION STUDY:}

In this part, the researcher chooses museums as one of smart applications in children spaces. Two case studies will be analyzed depending on the theoretical part illustrated in terms of the impact of technological development on the architectural space of the child and the design dimension affecting the child spaces.

Two museums have been chosen including different activities for children, the first case study 
is the children's museum of Houston in USA representing the standard recognized design of museums and the second case study is Digital Art Museum by which it will illustrate the alteration in visualizing the space and correlating the digital technology in creating different environment.

\section{Process of Analytical study:}

1- Description of case studies and the different activities/ spaces provided in each.

2- Analysis of each case study based on the design dimensions (form, human, environmental and physical dimension) in terms of (Components of the architectural space, criteria for the visual vision of the space, criteria for the quality of the space)

3- Summary of the analysis in a matrix comparing results to show transformation in several aspects of application of technology in architecture form and space.

\section{7-1- Children's Museum of Houstan, USA}

\section{Table (4)}

\begin{tabular}{|l|l|}
\hline Children's Museum of Houstan, Texas, USA \\
\hline -provides family fun and children's activites, many community leadership opportunities \\
for teens, adults and groups.
\end{tabular}




\section{7-2 Digital Art Museum: Mori Building, Tokyo, 2018}

Table (5)

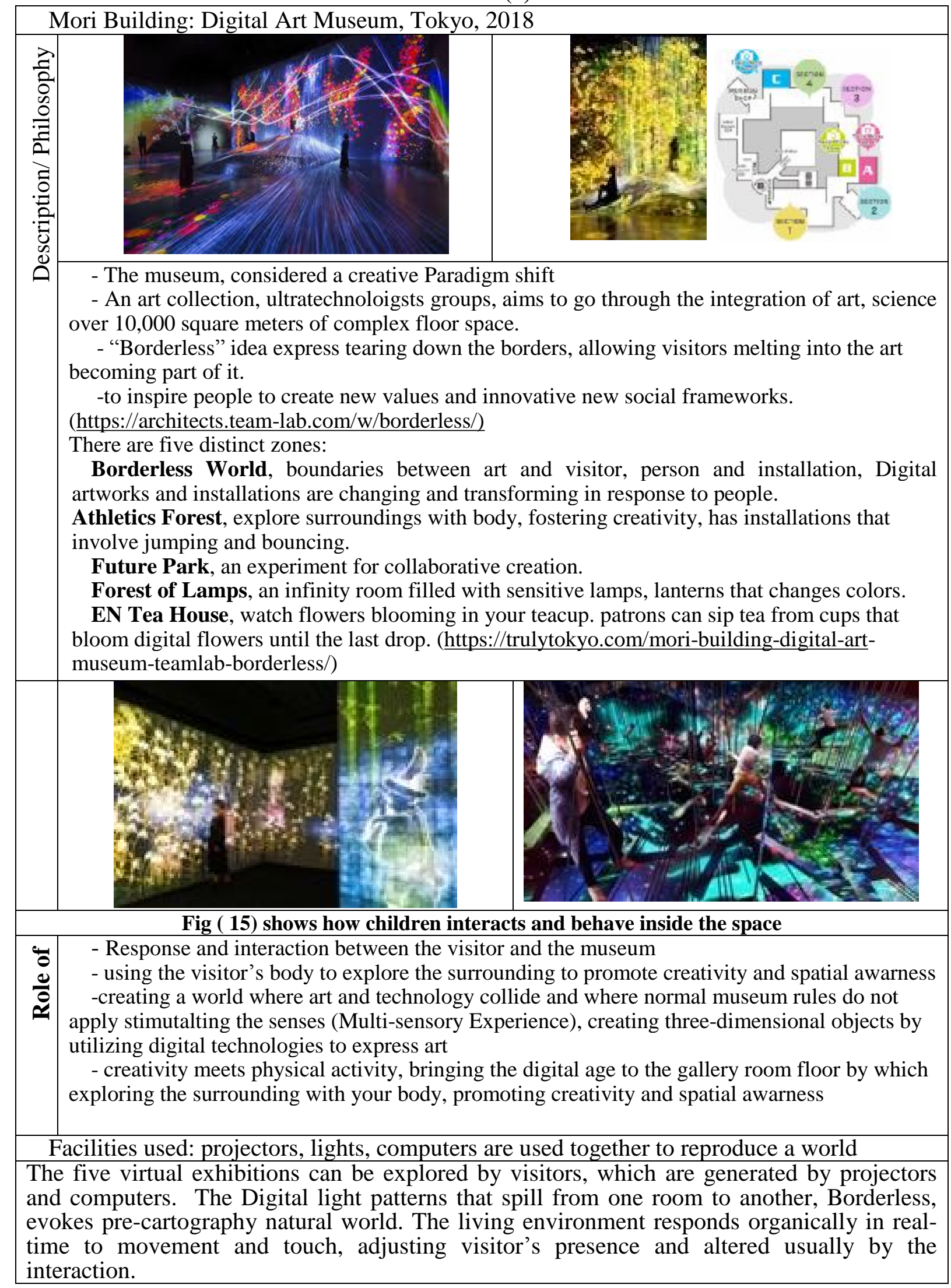




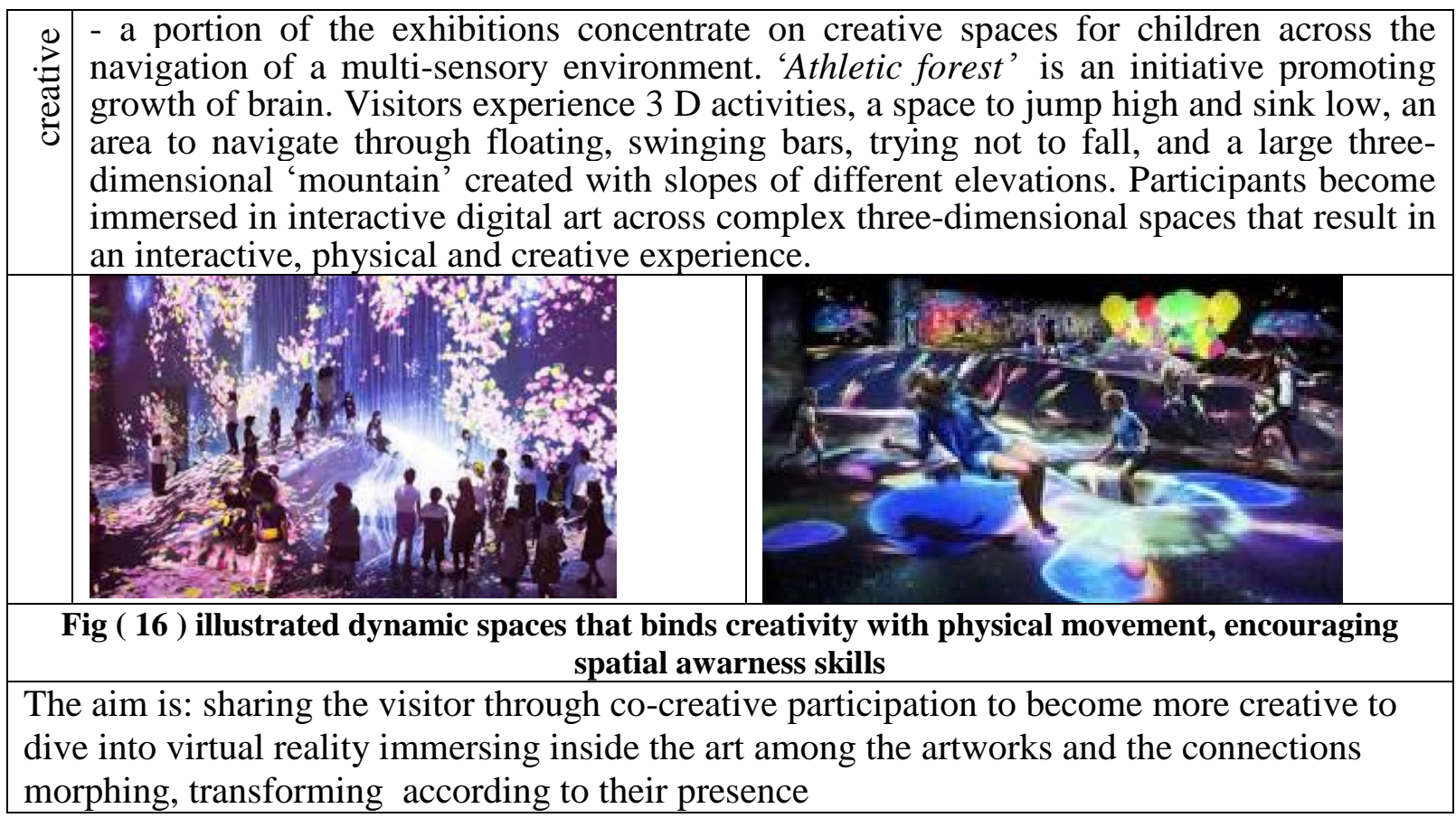

8- ANALYSIS OF CASE STUDY:

Table (6) illustrates summarized analysis of two children museums

\begin{tabular}{|c|c|c|c|c|c|c|c|c|}
\hline & \multicolumn{2}{|c|}{ Spatial Dimension } & \multicolumn{2}{|c|}{$\begin{array}{l}\text { The human } \\
\text { Dimension }\end{array}$} & \multicolumn{2}{|c|}{$\begin{array}{l}\text { Environmental } \\
\text { Dimension }\end{array}$} & \multicolumn{2}{|c|}{ Physical Dimension } \\
\hline & $\begin{array}{l}\text { Childre } \\
\text { n } \\
\text { Museu } \\
\text { m of } \\
\text { Housto } \\
\text { n }\end{array}$ & $\begin{array}{l}\text { Mori } \\
\text { Digital } \\
\text { Art } \\
\text { Museum }\end{array}$ & $\begin{array}{l}\text { Children } \\
\text { Museum } \\
\text { of } \\
\text { Houston }\end{array}$ & $\begin{array}{l}\text { Mori } \\
\text { Digital } \\
\text { Art } \\
\text { Museum }\end{array}$ & $\begin{array}{l}\text { Children } \\
\text { Museum } \\
\text { of } \\
\text { Houston }\end{array}$ & $\begin{array}{l}\text { Mori } \\
\text { Digital } \\
\text { Art } \\
\text { Museum }\end{array}$ & $\begin{array}{l}\text { Children } \\
\text { Museum } \\
\text { of } \\
\text { Houston }\end{array}$ & \begin{tabular}{|l|} 
Mori \\
Digital Art \\
Museum \\
\end{tabular} \\
\hline $\begin{array}{l}\text { Components of } \\
\text { the } \\
\text { architectural } \\
\text { space: }\end{array}$ & 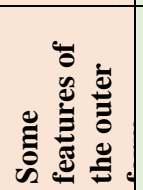 & 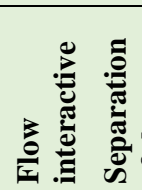 & 匏 & 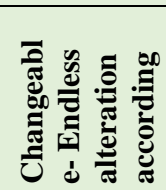 & 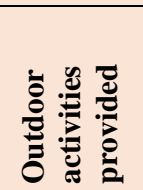 & 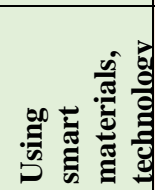 & 芯芯 & 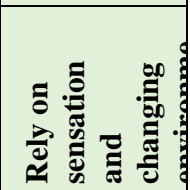 \\
\hline
\end{tabular}

\begin{tabular}{|c|c|c|c|c|c|c|c|}
\hline Results & \multicolumn{7}{|c|}{$\begin{array}{l}\text { Architectural spaces transformed to dynamics, interactive, movable. Such flexible spaces } \\
\text { created helped in providing creative spaces for children and to interact positively }\end{array}$} \\
\hline $\begin{array}{l}\text { Special criteria } \\
\text { for the visual } \\
\text { vision of the } \\
\text { space: }\end{array}$ & 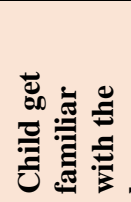 & 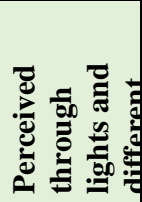 & 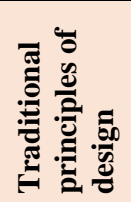 & 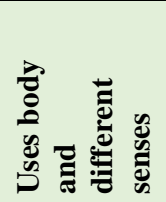 & 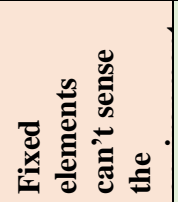 & 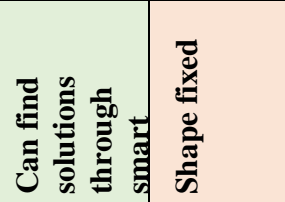 & 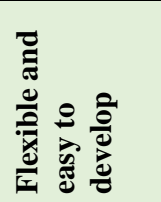 \\
\hline Results & \multicolumn{7}{|c|}{$\begin{array}{l}\text { Architectural Composition altered to communication, spatial elements, became easy to develop } \\
\text { the spaces to house various technologies developing children imaginative skills and abilities } \\
\text { promoting the child's creative thinking. }\end{array}$} \\
\hline $\begin{array}{l}\text { Criteria for the } \\
\text { quality of the } \\
\text { space: }\end{array}$ & 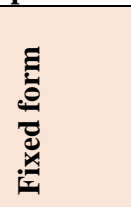 & 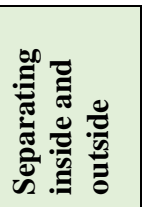 & 壱 & 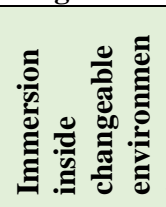 & 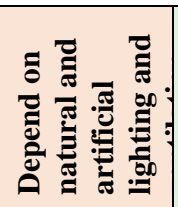 & 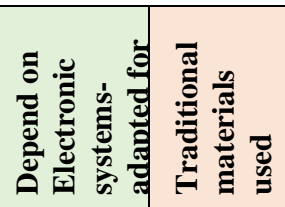 & 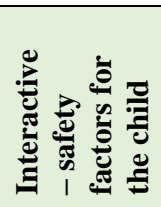 \\
\hline Results & \multicolumn{7}{|c|}{$\begin{array}{l}\text { Architecture space transformed to interactive by the use of smart materials and IoT } \\
\text { adaptability, affecting the characteristics of the space form. spaces include electronic systems } \\
\text { and innovative technological methods, providing new dimensions to perceive the spaces to suit } \\
\text { the child. }\end{array}$} \\
\hline Conclusion & \multicolumn{7}{|c|}{$\begin{array}{l}\text { Smart materials/ technologies bring opportunities to enhance architecture creative spaces for } \\
\text { children. }\end{array}$} \\
\hline
\end{tabular}




\section{8-1 Implementing smart technologies as a tool to stimulate creativity and imagination for children:}

Creative activities help children to develop attention skills and cognitive learning. It encourages them to come up with innovative ideas and think outside of the box since creativity involves exploration and problem solving. Experts put some methods in order to foster and encourage children creativity include: -a space for creating, allow a free time, help kids activate their senses, discuss creativity, cultivate creative critical thinking, avoid managing, help kids pursue their passions Analysis of the case studies provide us with some lessons about application of smart technologies in children spaces. The proposed ideas to be implemented in children spaces based on the analysis and literature review shown Table (7), followed by a suggested strategy to implement technology in Architectural spaces.

Table ( 7 ) illustrates some proposed ideas to consider implementation smart technologies for children spaces (Author)

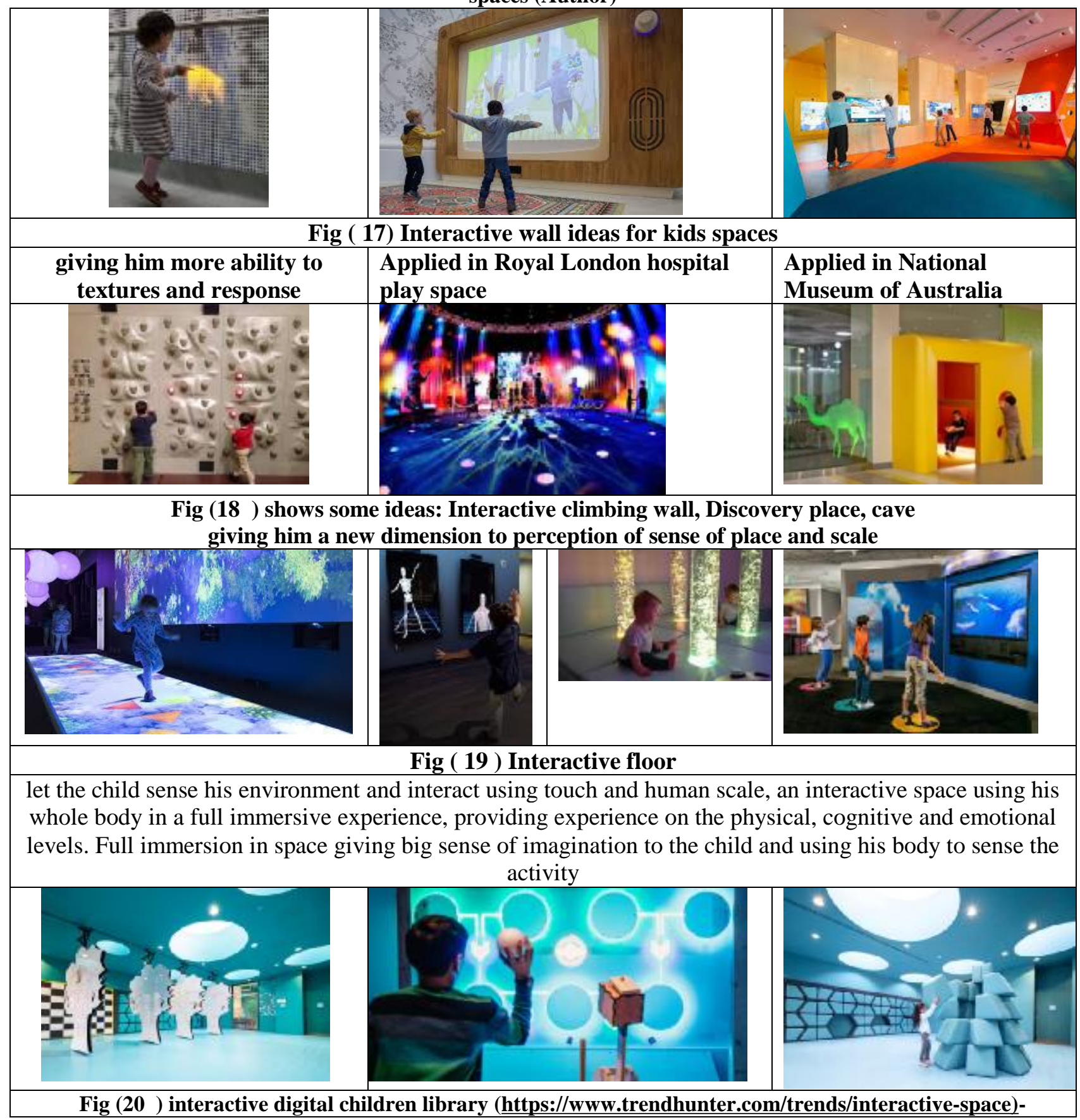




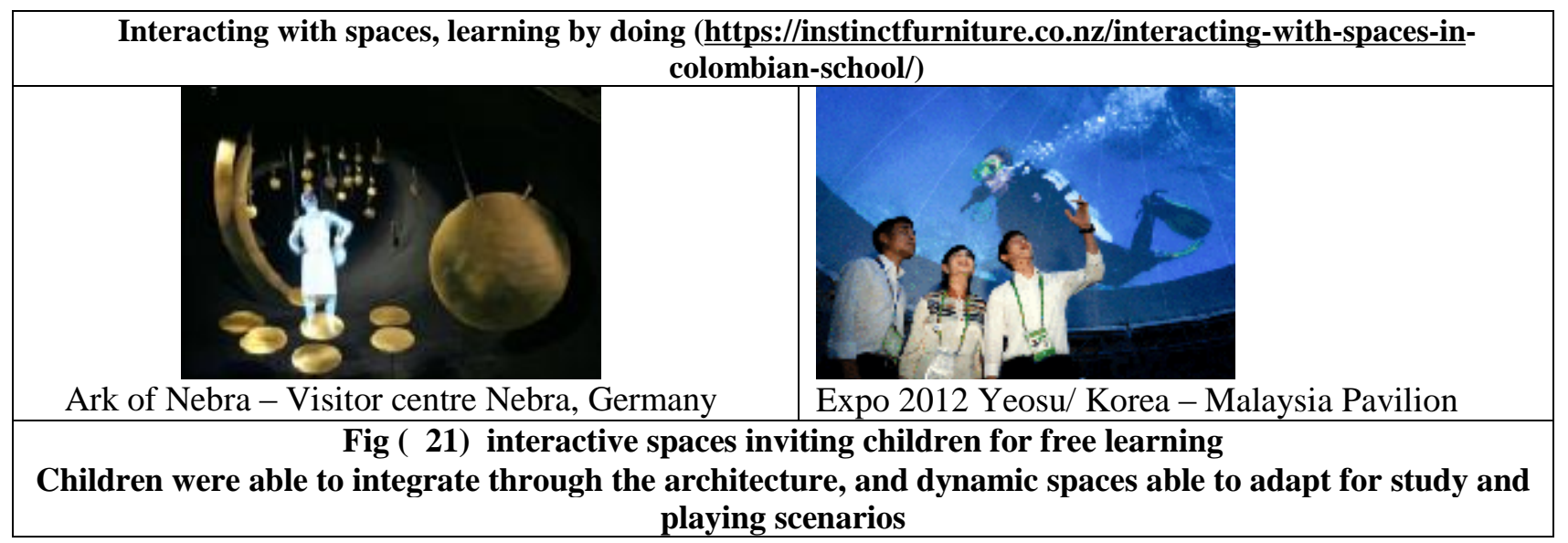

\section{Different tracks of the implementation of Smart technology and the effects (Author)}

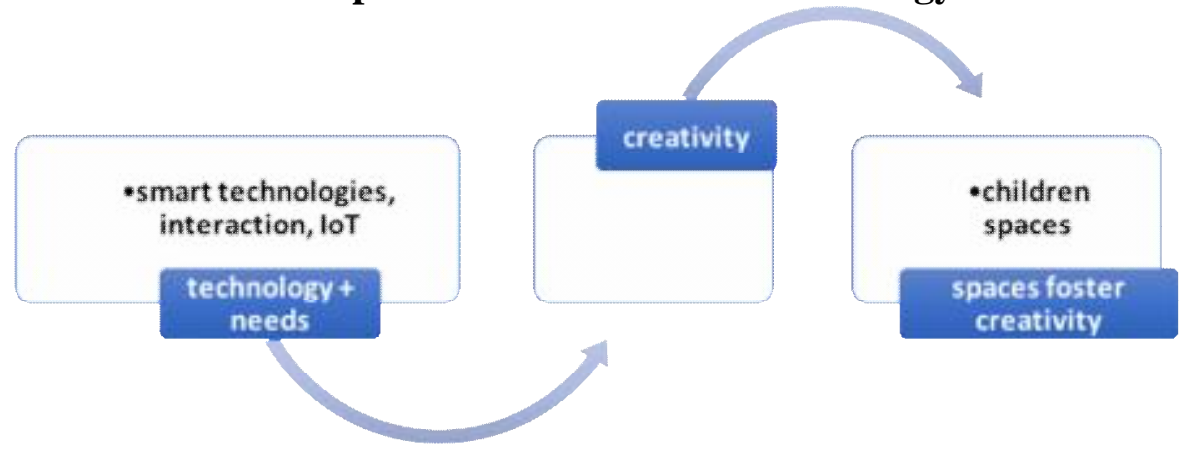

\section{Suggested strategy to implement Technology in Architectural Spaces (Author)}

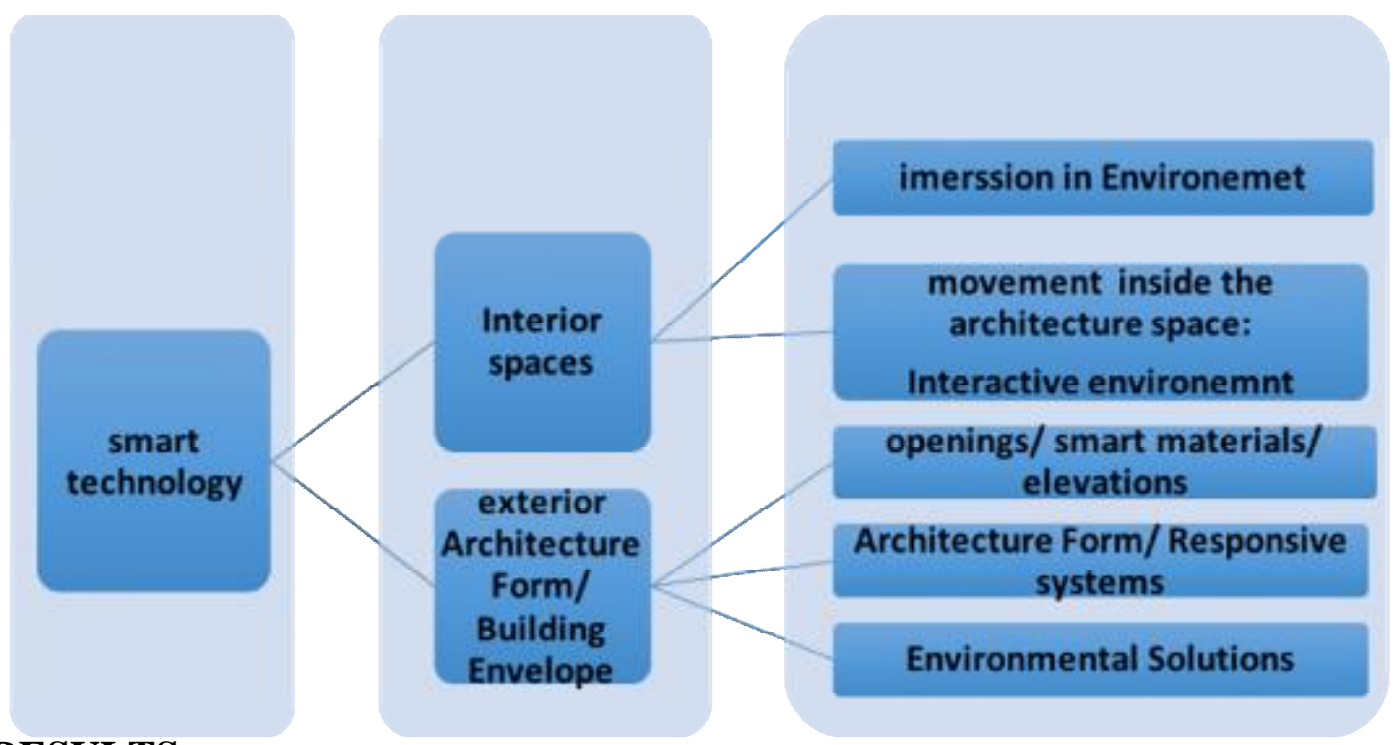

\section{9-RESULTS:}

1-Smart technology has helped to create smart environments and opened up new opportunities to solve previous problems and give a new aesthetic dimension.

2-The manifestation of new technologies such as Internet of Things IoT, emphasis on providing environments and spaces that serve the human and provide him with comfort and safety

3-Digital technology has given new dimensions of time and space where the concept of defining and describing the architectural space in the third dimension has changed, but 
extended to the element of time. The emergence of new spaces in architecture relied on digital entertainment and science fiction suitable for different ages

4-Technology and smart materials contributed to the response and solutions in the child's creative environment. Architectural design directed to the child must take into account the creative aspect of its development and stimulation, both in the outer spaces or interior Architectural Spaces.

5-Form of the child's Architectural spaces have been altered and transformed from conventional static spaces to dynamic interacting spaces offering flexible and adaptive spaces to children of different age groups. As well as interaction with the surrounding environment.

6-Appearance of new projects such as digital art museums aimed at inspiring the individual or create new social values and frameworks not only about the relationship of man with the space, but extended to include the relationship of the individual to the other. Where it aimed to engage the visitor with an innovative and creative experience

7- The development of creativity in the child helps him to develop different skills. Where he uses his imagination and encourages him to reach new ideas and think creatively and help him to solve problems. Where the role of architecture in providing creative spaces enhances the child's use of his senses and body and encourage the spirit of discovery and experimentation.

8- Smart technology included applications in both exterior and interior architectural spaces. External features included openings - facades- responsive systems and environmental solutions. The interior spaces included immersive environments, walk-through spaces and interactive environments.

9-Borderless: the idea of eliminating the borders between spaces which have been emerged by the new technology giving new dimensions in visual perception and increase awareness towards the spatial configuration increasing his imagination and intellectual skills towards his surround

10-Interaction: giving new and unexpected feelings by which endless responses can be offered

\section{0-DISCUSSION}

The purpose of this research was to investigate the potentials and role of smart materials and technologies and introduce the emergence of the Internet of Things to propose flexible creative environment for children. It was found that provision a range of spaces and good architectural elements requires the use of the child's diverse human needs and thus affects the child's response to the outside world. The major findings of the study are that Technological development has great impact in designing the architectural space of the child, Components of the architectural space, criteria for visual vision of space and criteria for space quality.

The study demonstrated the role of technological development in the development of architectural spaces for Children to Provide solutions to many complex human problems of the child, generation of new concepts of communication and interaction among them to exchange experiences, Provide the possibilities and facilities to know the extent of creativity of the child since its inception, satisfy his curiosity with experience and self-teaching and rapid incorporation of methods of communication and the speed of information transfer.

It is important to highlight that Smart technologies pave the road to new ideas in architectural design. This study showed some of its applications and how it gives different perception of time and space. Some advantages and disadvantages for implementing these technologies in Children Architectural spaces is summarized as follows Table (8): 
Table (8) shows some advantages and disadvantages of integrating smart materials/ technology in children advantages spaces on the child development (Author)

\begin{tabular}{|c|c|}
\hline \multicolumn{2}{|c|}{ spaces on the child development (Author) } \\
\hline advantages & disadvantages \\
\hline $\begin{array}{l}\text { giving the child new ideas to explore the } \\
\text { environment around him }\end{array}$ & $\begin{array}{l}\text {-Misuse of perception which may need } \\
\text { guidance }\end{array}$ \\
\hline $\begin{array}{l}\text { provide the child with the ability to live in } \\
\text { a real experience physically and emotionally }\end{array}$ & $\begin{array}{l}\text { - Further studies may be conducted to measure } \\
\text { effects of such technology on certain ages }\end{array}$ \\
\hline $\begin{array}{l}\text { utilizing the child's senses in exploring } \\
\text { new sciences }\end{array}$ & $\begin{array}{l}\text { - Some children may be afraid to try which } \\
\text { needs more motivation and guidance in these } \\
\text { cases }\end{array}$ \\
\hline increases motivation to finish tasks & $\begin{array}{l}\text { - Technology can affect children's social } \\
\text { development to human relationships } \\
\text { affecting their focus }\end{array}$ \\
\hline develops problem solving skills & $\begin{array}{l}\text { - Use of technology can have negative } \\
\text { consequences on physical health causing } \\
\text { vision problems }\end{array}$ \\
\hline more dynamic spatial skills & $\begin{array}{l}\text { - Being over connected can cause psychological } \\
\text { issues such as distraction }\end{array}$ \\
\hline $\begin{array}{l}\text { enhances social interaction skills, the } \\
\text { navigation of a multi-sensory environment, } \\
\text { fostering the growth of the brain, and guiding } \\
\text { spatial awareness skills. }\end{array}$ & - May affect mental health \\
\hline higher capacity for visual attention & - Slower development in social and life skills \\
\hline
\end{tabular}

\section{1-CONCLUSION}

Technology gives new dimension in aesthetics as it has the the possibility to change during time. Interaction between a user and space, making the space more visible, more dynamic, accessible and more friendly.

Smart Materials played a major role in changing dimensions of architectural space and influenced by new techniques such as Internet of Things IoT to create new dimensions of time and architectural space.

IoT (Internet of Things) emerged daily life and plays an important role in changing dealing with the architecture space, using automated processes to automatically control the building's operations.

These techniques have contributed to enhancing the creativity and imagination of the children, which requires increasing awareness of the educational goals, taking into consideration the technological development to keep alongside of the era and reflect it by providing creative spaces that serve the children as they are considered the main pillars who strengthen their creative sense and develop their imagination and thinking.

\section{2- RECOMMENDATIONS}

- Benefit of Smart technologies that transforms Architecture design, through the expansion of interactive surfaces, to discover new design possibilities.

- encourage multidisciplinary collaboration between Architects and Technologists.

-Benefit of nanotechnology which offers superior potentials result in novel smart architectural solutions.

-Technology can affect different disciplines: Education, Architectural spaces and Environmental aspects. It is recommended that additional research can be done in different areas that affect directly child's creativity development. 


\section{REFERENCES}

1. Manuel Kretzer, 2017. "Information Materials: Smart Materials for Adaptive Architecture", Springer International Publishing.

2. Mohamed, Abeer Samy Yousef, 2017. "Smart Material Innovative Technologies in Architecture; Towards Innovative Design Paradigm", International Conference Alternative and Renewable Energy Quest, AREQ 2017, Spain. Science Direct, Energy Proceedia, Elsevier.

3. Michelle Addington and Daniel Schodek, 2005. "Smart Materials and New Technologies for architecture design professions", Elsevier, Architectural Press.

4. Herrington, Susan; Lesmeister, Chandra; Nicholls, Jamie \& Stefiuk, Kate, 2007. 7Cs an information guide to young children's outdoor play space, Westcoast Child Care Resource Centre \& Consortium for Health, Intervention, Learning and Development (CHILD)

5. Majid Gharabaghi, Asadollah Naghdi, 2014. "Identifying Smart Materials and applying them in Residential Spaces in Cold Climate case study: City of Hamadan", International Research Journal of Applied and Basic Sciences, Science Explorer Publications, IRJAB S.

6. Jonathan gilder, Derek clements - Croome, 2014. "Using smart materials to mimic nature in Architecture", CIBE Intelligent Group.

7. Al-Baldawi, Mahmmed Thabit, 2015. "Application of Smart Materials in the interior design of smart houses", Civil and Environmental Research, ISSN 2224-5790.

8. Boguslawa Konarzewska, 2015. "Smart materials in Architecture: Useful Tools with Practical applications or fascinating Inventions for Experimental Design?", IOP Conference Series: Materials and Engineering.

9. Yogi, Manas Kumar, K Ganga Devi Bhavani, 2018. "Green IoT, current trends, future Directions", International Journal of Advance Research and Innovation", Volume 6, Issue 3, 156-158 ISSN $2347-3258$.

10. Nitesh Dogne, Ashish Choudhary, 2017. "Smart Construction materials and techniques", AICMT: National Conference ON Alternative \& Innovation Construction materials and Techniques.

11. Elif Süyük Makakli, 2017. "Potential of Smart Materials for sustainable Architecture", The journal of Academic Social Science Studies, IASSS.

12. Hongjian Sun, Chao Wang, Bashar I. Ahmad, 2018. "From Internet of Things to Smart Cities. Enabling Technologies". CRC Press. Taylor \& Francis Group. Achapman \& Hall Book.

13. Mahmoud Wahid Saidam, Karam M. Al-Obaidi, Hazreena Hussein and Muhammad Azzam Ismail, 2017. "The application of Smart materials in building Facades", Eco. Env. \& Cons.

14. Sherif Mohamed Sabry Elattar, 2013. "Smart Structures and material technologies in Architecture applications", Scientific Research and Essays, academic Journals.

15. Michelle Addington, Editor: Werner Lang, Aurora McClain, 2007. "Smart Materials and Sustainability", School of Architecture, The University of Texas at Austin, Center for Sustainable Development.

16. Mahmoud Wahid, Karam M. Al-Obaidi, Hazreena Hussein and Muhammad Azzam Ismail, 2017. "The application of smart materials in building facades", Eco. Env. \& Cons. 23 (Nov.): pp. (S8-S11)

17. Sara Nabil, David s. Kirk, Thomas Plotz, Julie Trueman, David Chatting, Dmitry Dereshev, Patrick Olivier, 2017. "Interioractive: Smart Materials in the Hands of Designers and Architects for Designing Interactive Interiors", New University, ePrints.

18. Swabarna Roy, Honey Mishra and B. G. Mohapatro, 2016. "Creating Sustainable environment using smart materials in smart structures", Indian Journal of Science and Technology, vol. 9 (30), ISSN (Online): 0974-5645.

19. M. Ghorbanzadeh \& A. Nezami, 2010. "Smart architecture contribution to achieving sustainable architecture realization", Eco - Architecture III, WIT Transactions on Ecology and the Environment, Vol. 128, WIT Press, ISSN 1743 - 3541 (ON-LINE)

20. J. Gopi Krishna, J.R. Thirumal, 2015. "Application of Smart materials in smart structure", International Journal of Innovative Research in Science, Engineering and Technology, ISSN(Online): 2319-8753, Vol. 4, Issue 7. 
21. Kretzer, M., 2017. "Information Materials: Smart Materials for Adaptive Architecture", Springer, ISBN 978-3-319-35148-3

22. Jose Daveiga, Paulo Ferreira,2005. "Smart and Nano Materials in Architecture", ACADIA05: Smart Architecture

23. Josh SIIMS,2016. "Smart buildings are about sustainability - but also about improving lives", https://www.scmp.com/magazines/style/article/1931556/smart-buildings-arenot-only-about-saving-energy-and-being

24. Mohammad Javad Sadeghi, Payam Masudifar, Foad Faizi, 2011. "The function of Smart Material's behavior in architecture", International Conference on Intelligent Building and Management, Proc. Of CSIT vol. 5, IACSIT Press, Singapore.

25. Mary Guzowski, 2010. "Towards Zero Energy Architecture - New solar design", Laurence king publishing, London.

26. Yasmine Talaat Ahmed Nasr, 2017. "Using Smart materials to mimic Nature in Architecture", Master Thesis, Department of Architecture, Faculty of Engineering, University of Alexandria.

27. Ahmed Totonchi, 2014. "Smart Buildings Based on Internet of Things: A systematic Review",

28. Ayśin Sev, Meltem Ezel, 2014. "Nanotechnology Innovations for the Sustainable Buildings of the Future" World Academy of Science, Engineering and TechnologyInternational Journal of Architectural and Environmental Engineering, Vol:8, No:8.

29. Joanna Tymkiewicz, 2014. "Technological Aesthetics of Modern Facades". Technical Transactions: Architecture.

30. Ellika Taveres- Cachat, Steinar Grynning, Judith Thomsen, Stephan Selkowitz, 2019. "Responsive building envelope concepts in zero emission neighborhoods and smart cities" - A roadmap to implementation, Building and Environment 149, science Direct, Elsevier, $446-457$

31. Ali Raafat, 2007. "Environmental Cycle Future Architecture $5^{\text {th }}$ Volume", Triad of Architectural Creativity, Inter Consult Research Center.

32. Gehan Ahmed Ebrahim, 2016. "The feasibility study of designing smart elderly Homes in an efficient way"

33. Macro Casini, 2018. "Smart Buildings: Advanced Materials and Nanotechnology to improve Energy"

34. Eunil Park, Angel P. del Pobil and Sang Jib Kwon, 2018. "The role of internet of things in Smart Cities: Technology Roadmap-oriented Approaches”, Sustainability, 10, 1388; doi:10.3390/su10051388, MDPI.

35. Nilesh Y. Jadhav, 2016. "Green Energy and Technology: Green and Smart Buildings": Advanced Technology Options, Springer.

36. Franco Cicirelli. Antonio Guerrieri. Carlo Mastroianni, 2018. "The Internet of Things for Smart Urban Ecosystems", Springer.

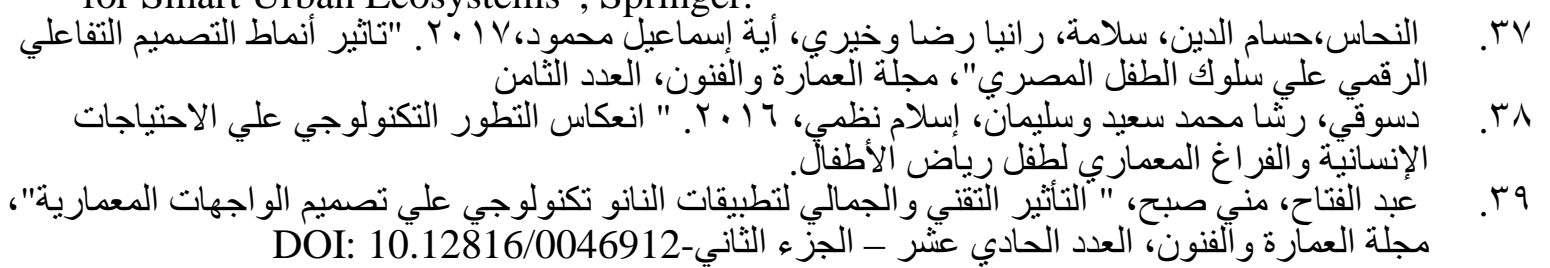

40. Tom Dobbins, 2018. "Shaping the future: what to consider when designing for children": (https://www.archdaily.com/901151/shaping-the-future-what-to-considerwhen-designing-for-children

41. Mori teamLab Architects, (https://architects.team-lab.com/w/borderless/)

42. https://www.archdaily.com/901151/shaping-the-future-what-to-consider-whendesigning-for-children

43. (https://trulytokyo.com/mori-building-digital-art-museum-teamlab-borderless/)

44. (https://www.trendhunter.com/trends/interactive-space)-

45. (https://instinctfurniture.co.nz/interacting-with-spaces-in-colombian-school/) 